\title{
Notes on the vocalizations of Green-and-black Fruiteater (Pipreola riefferii)
}

\section{Peter Boesman}

In the following we briefly analyze and compare voice of the different races of Green-andblack Fruiteater (Pipreola riefferii). We also try to quantify the extent of any vocal differences using the criteria proposed by Tobias et al. (2010), as a support for taxonomic review. We have made use of sound recordings available on-line from Xeno Canto (XC) and Macaulay Library (ML).

Snow (2015) indicates race tallmonorum to be quite distinctive, and Berv et al. (2014) highlights the genetic difference in race melanolaema, both suggesting species-level differences. I have therefore tried to compare tallmanorum and melanolaema with the remaining races.

Song is a variable number of short high-pitched notes followed by a downslurred drawn-out whistle (Fig. 1). Both the series of short notes and slur are also given separately, possibly as calls.

Comparison of full songs:

melanolaema $(n=7)$

\# intro notes

max. freq.

min.freq.

length intro notes

length slur

freq range slur

\author{
2-12 \\ $8900-10100 \mathrm{~Hz}$ \\ $6200-6600 \mathrm{~Hz}$ \\ $0.04-0.06 \mathrm{~s}$ \\ $0.65-1.5 \mathrm{~s}$ \\ $2100-3500 \mathrm{~Hz}$
}

tallmanorum

We have only found 2 recordings of short note series(note length and max. freq. similar to 'other races'). Full song with downslurred whistle does seem to exist however, as mentioned in Snow (2015), erroneously as a distinctive feature for tallmanorum however.

other $\operatorname{races}(n=7)$

\# intro notes

max. freq.

min.freq.

length intro notes

length slur

freq range slur

\author{
6-16 \\ $7700-8900 \mathrm{~Hz}$ \\ $5300-6200 \mathrm{~Hz}$ \\ 0.04-0.06s \\ $0.8-1.4 \mathrm{~s}$ \\ $2000-2400 \mathrm{~Hz}$
}



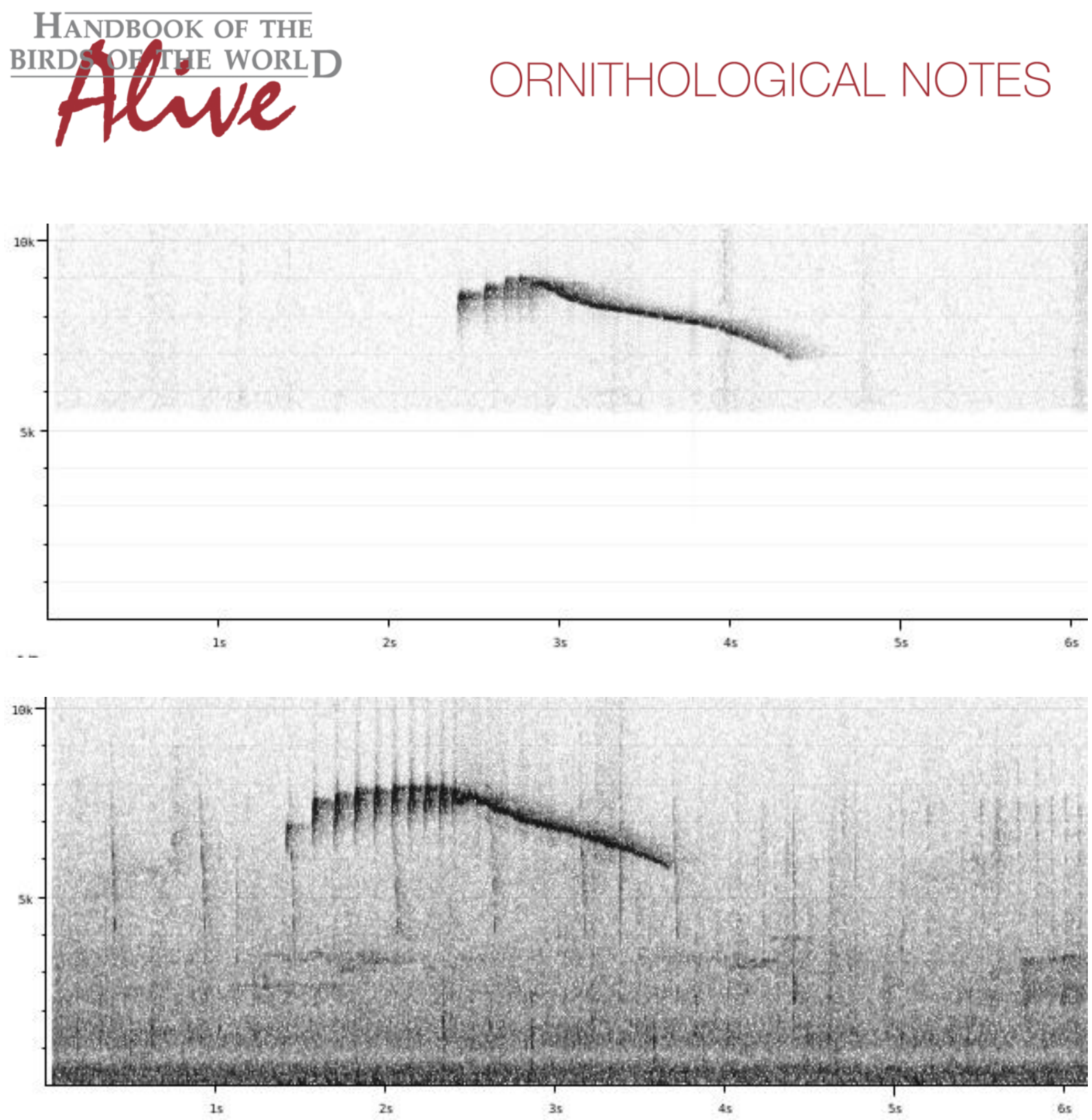

Figure 1: typical song of melanolaema (top) and other races (bottom)

Many of the basic sound parameters show considerable overlap, but melanolaema typically is at slightly higher frequencies (score 1-2). Also, there are mostly only a few introductory notes with rarely a longer series, while the 'other races' always have a fairly long to long series (score 1). When applying Tobias criteria, this would lead to a total vocal score of 2-3.

For tallmanorum, we haven' t found any evidence of distinctiveness in voice. 

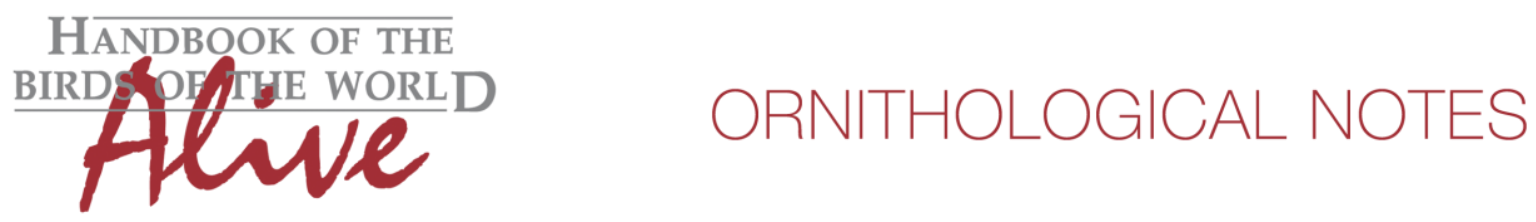

This note was finalized on 10th June 2015 , using sound recordings available on-line at that moment. We would like to thank in particular the many sound recordists who placed their recordings for this species on XC and ML.

\section{References}

Berv, J.S. and Prum, R.O. (2014). A comprehensive multilocus phylogeny of the Neotropical cotingas (Cotingidae, Aves) with a comparative evolutionary analysis of breeding system and plumage dimorphism and a revised phylogenetic classification. Mol. Phylogenet. Evol.

81: 120-136.

Snow, D. (2015). Green-and-black Fruiteater (Pipreola riefferii). In: del Hoyo, J., Elliott, A., Sargatal, J., Christie, D.A. \& de Juana, E. (eds.). Handbook of the Birds of the World Alive. Lynx Edicions, Barcelona. (retrieved from http://www.hbw.com/node/57004 on 10 June 2015).

Tobias, J.A., Seddon, N., Spottiswoode, C.N., Pilgrim, J.D., Fishpool, L.D.C. \& Collar, N.J. (2010). Quantitative criteria for species delimitation. Ibis 152(4): 724-746.

\section{Recommended citation}

Boesman, P. (2016). Notes on the vocalizations of Green-and-black Fruiteater (Pipreola riefferii). HBW Alive Ornithological Note 111. In: Handbook of the Birds of the World Alive. Lynx Edicions, Barcelona. (retrieved from http://www.hbw.com/node/932016 on 2 August 2016). 